\title{
IAMJ
}

INTERNATIONAL

AYURVEDIC

MEDICAL JOURNAL

Review Article

ISSN: 23205091

Impact Factor: 5.344

\section{DIABETES INDUCED MICROALBUMINURIA - A CRITICAL REVIEW}

\author{
Binsha Salim ${ }^{1}$, Madhuri Devi N² \\ PG scholar, Govt Ayurveda Medical College, Tripunithura, Kerala, India \\ Former Professor and HOD, Govt Ayurveda Medical College, Tripunithura, Kerala, India
}

Corresponding Authors: drbinshasalim@gmail.com

\section{https://doi.org/10.46607/iamj2808112020}

(Published online: November 2020)

Open Access

(C) International Ayurvedic Medical Journal, India 2020

Article Received: 30/10/2020 - Peer Reviewed: 08/11/2020 - Accepted for Publication: 14/11/2020

Check for updates

\begin{abstract}
Microalbuminuria is a marker and a risk factor of diabetic renal complications commences its role in pathogenesis of nephropathy at its third stage, the stage of incipient nephropathy. Microalbuminuria is followed by overt nephropathy and end- stage renal disease of irreversible renal damage. Early detection of microalbuminuria has a decisive role in the healthy survival of diabetics. Urine albumin excretion rate and albumin creatinine ratio on timed urine samples, early morning samples or spot urine are of beneficial use. Ayurveda describes diabetes mellitus as Prameha roga in which the major pathogenesis takes precedence in Mootrasaya. Microalbuminuria can be described as Prameha Janya Vrikka Roga. It occurs due to Sanga (obstruction), Vimarga Gamana (abnormal movement) of albumin; one of the constituents of Raktadhatu (blood) through Rakta and Mootra Vaha Srotas (channels of blood and urine). Medicines which are Pramehaghna (anti-diabetic), Mootra and Raktavaha Srothosodhana (cleanse the channels) may be of good worth to rectify the pathology of microalbuminuria providing an improved life for diabetics.
\end{abstract}

Keywords: Binsha Salim, Madhuri Devi, microalbuminuria, Ayurveda

\section{INTRODUCTION}

An unusually increased glycemic status in blood vessels can do certain scornful effect on the acceptable purpose of vital organs. The regular victims of this metabolic catastrophe are retina, nephron and neuron guide to the development of retinopathy, nephropathy and neuropathy in uncontrolled diabetics. Among them 
diabetic nephropathy is one of the most leading cause of mortality. ${ }^{[1]}$ The 5 stages of pathogenesis in diabetic nephropathy are Stage of hypertrophy and hyper filtration, Stage of structural change without functional alteration, Stage of microalbuminuria, Stage of overt nephropathy and Stage of advanced nephropathy. ${ }^{[2]}$ Early detectable stage of diabetic nephropathy is microalbuminuria. It is characterized by excretion of albumin 30-300 mg/day in 24- hour urine sample. ${ }^{[3]}$ International Diabetic Foundation recommends the annual screening of microalbuminuria after every 5 years of onset of type 1 diabetes mellitus and at the time of the diagnosis of type 2 diabetes mellitus and yearly thereafter. ${ }^{[4]}$ Ayurveda is popular among public in treatment of diabetes, hence a prompt discussion of microalbuminuria in Ayurvedic vista is adequate. Almost all classical compendiums of Ayurveda describe Prameha roga (obstinate urinary disorder) which is nearly equivalent with the features of diabetes mellitus.

\section{The findspot of microalbuminuria in Prameha}

In Ayurveda, the pathology of any disease is described as 6 opportunity for treatment named Shad-kriya kala include Sanchaya (accumulation), Prakopa (excitement from the principal abode), Prasara (movement from the abode), Sthana samsraya (localization), Vyatka (manifestation) and Bheda (split up into complications). ${ }^{[5]}$ The findspot of microalbuminuria in Prameha is at $6^{\text {th }}$ kriyakala- the stage of Bheda. It can be termed as a Prameha Janya Upadrava (diabetes induced complication)

\section{Etiology of microalbuminuria in diabetes mellitus}

Etiology of microalbuminuria can be compared with the cause of Prameha Upadrava depicted in the Nyayacandirika Vyakhya (commentary on Susruta Samhita- Nidana Sthana) by Acharya Gayadasa (Table 1).

Table 1: Etiology of microalbuminuria

\begin{tabular}{|c|c|}
\hline Ayurveda- Etiology of prameha upadrava ${ }^{[6]}$ & Modern - Etiology of diabetic nephropathy ${ }^{[7]}$ \\
\hline 1. Prameha upekshaya (lack of adequate treatment) & 1. Long standing uncontrolled diabetes. \\
\hline 2. Prameha atiyoga (severity of disease) & Persistent hyperglycemia \\
\hline a. Roga atiyoga(hyperglycemia) & 2. Chronicity \\
\hline b. Kala atiyoga(chronicity) & 3. Hypertension \\
\hline 3. Dushtamedas (vitiation of Medo Dhatu) & 4. Dyslipidemia \\
\hline
\end{tabular}

Pathogenesis: It can be termed as a Prameha janya vrkkaroga. Therefor all dosha factors takes part in Prameha roga appears as a factor of pathogenesis in microalbuminuria.
Samprapti ghataka (pathogenic factors): Dosha in Samprapthi:- Dosha involved in the pathogenesis are the factors which participates in urine formation and involves in the pathogenesis of Prameha (Table 2)

Table 2: Dosha involved in Samprapthi

\begin{tabular}{|c|c|}
\hline Tridosha & Types of dosha involved \\
\hline \multirow[t]{3}{*}{ Vata } & $\begin{array}{l}\text { Samana vayu; urine formation- Ahara rasa drava bhava (liquid part of the food) turned into urine. Samana } \\
\text { vayu present in all Udakavaha srotas (channels of fluids) }\end{array}$ \\
\hline & Apana vayu; Mutra utsarga (excretion of urine) ${ }^{[9]}$ \\
\hline & Vyana vayu; responsible for Gati(movement) ${ }^{[9]}$ \\
\hline Pitha & Pachaka pitha- on Maladhara kala which separates Mutra ${ }^{[9]}$ \\
\hline Kapha & Avalambaka kapha - Udaka karma ${ }^{[9]}$ \\
\hline
\end{tabular}


Table 3: Samprapti of microalbuminuria

\begin{tabular}{|c|c|c|}
\hline & Ayurvedic view & Conventional view \\
\hline $\begin{array}{l}\text { Nidana } \\
\text { (etiology) }\end{array}$ & Deergha kalasthita prameha, Prameha atiyoga & Long duration of diabetes with poor glycemic control \\
\hline $\begin{array}{l}\text { Pathogenic } \\
\text { factors }\end{array}$ & $\begin{array}{l}\text { Samanavata vyana vata, Avalambaka Kapha, } \\
\text { Kledaka kapha, Pachaka pitta got vitiated }{ }^{[9]}\end{array}$ & Alteration in the physiology of urine formation \\
\hline Stage1 & Mootradhara kala vrdhi and Mootravrdhi & $\begin{array}{l}\text { Stage of hypertrophy and increased GFR. Excess elimina- } \\
\text { tion of glucose through urine }\end{array}$ \\
\hline Stage 2 & Ayanadourbalya of Mootra vahasrotas & GBM thickening, mild or severe mesangial expansion \\
\hline Stage 3 & $\begin{array}{l}\text { Excess loss of Dhatusaramsha (albu- } \\
\text { min)through urine }\end{array}$ & $\begin{array}{l}\text { Nodular sclerosis, lower molecular weight protein-albumin } \\
\text { is filtered and appeared in urine. (Microalbuminuria) }\end{array}$ \\
\hline Stage 4 & Dhatuksaya and worsening of health of $V r k k a$ & $\begin{array}{l}\text { Advanced diabetic glomerulosclerosis that includes tubu- } \\
\text { lointerstitial lesions and vascular lesions }\end{array}$ \\
\hline Stage 5 & $\begin{array}{l}\text { Final irreversible damage of Mootravaha sam- } \\
\text { sthana }\end{array}$ & $\begin{array}{l}\text { End-stage kidney disease with GFR }<15 \mathrm{ml} / \mathrm{min} / 1.73 \mathrm{~m} 2 \\
\text { [10] }\end{array}$ \\
\hline
\end{tabular}

*GBM - Glomerular Basement Membrane

Dushyas: All Dushya of Prameha include Medas, Mamsa, Vasa, Majja, Kleda, Sukra, Sonita, Rasa and Ojas ${ }^{[11]}$

Structural changes take place in;

- Mootradharakala - nephron,

- Mootravahini, Sira (vessels)

- Asaya-Mootrasaya (urinary system)

Manifestation of the disease microalbuminuria and its prognosis is described in schematic representation comparing Ayurvedic and conventional view (Table 3). In general, Prameha causes Srotodushti on Raktavaha and Mutravaha Srotas leads to

1. Vimargagamana (impaired movement) of one of the constituents of Raktadhatu (albumin) into Bowman's capsule

2. Sanga - failure of reabsorption of albumin into renal capillaries

\section{Clinical features}

Poorvaroopa (prodromal symptoms)

\section{Stage of hyper filtration or hypertrophy}

- Glomerular filtration is exceeding than normal, Prabhoota mootrata(polyuria) the classical sign of Prameha.

- Elevated renal plasma flow

- Increased kidney size by $20 \%$

- It can be correlated as Mamsopacaya (hypertrophy) mentioned in Upadrava of Kaphaja Prameha (complications)

\section{Stage of structural glomerular lesion}

- Hemodynamic changes at earlier stage

- Basal membrane thickening and mesangial expan$\operatorname{sion}^{[2,10]}$

These are accumulation of Vaikruta dosha at nephron level, because of the continuous fatigue created by Deergha kaala madhumeha (persistent hyperglycemia).

\section{Roopa (signs and symptoms)}

The disease rarely exhibits any distinct symptom. Lakshanas like frothy urine - Aavila mootrata can be seen in some patients as a clinical sign. The condition cannot be equated with Phena meha or Sandra meha mentioned as Kaphaja prameha varieties in classics. Because microalbuminuria appears as a Deergha kala sthita prameha janya upadrava, but the above disease appears a manifestation of Kaphaja prameha. ${ }^{[12]}$

\section{Chikitsa - Diabetes induced microalbuminuria}

The goals of treatment are to control blood glucose level, hypertension and to reverse structural damage of nephrons including Bowmans capsules and glomerular capillaries in early stages and to control further renal damage. ${ }^{[13]}$ The modalities of treatments are Nidana parivarjana(removal of aetiology) by means of adequate treatment of diabetes(Pramehahara) along with early detection of microalbuminuria, Samprapthi Vighatana (rectify the pathology) and to clear Ayana dourbalya of Mootravaha srotas to provide structural integrity and to prevent the leakage of albumin through 
Mootradharakala. This is achieved by the rectification of Vimarga Gamana of albumin through Raktavahasrotas as well as Sanga of albumin Mootravahasrotas. Effective medications can be chosen from Prameha chikitsa which are Pramehahara (antidiabetic) and Srotosodhana (cleansing the channels from impurities-antioxidant anti-inflammatory etc.).

\section{CONCLUSION}

Prameha is quite similar in description to the disease of diabetes mellitus in reference to the clinical features and treatment. As regards the pathogenesis of microalbuminuria can be described under the concepts and principles of Ayurveda in its various aspects. Determination of Ayurvedic point of view in microalbuminuria will aid to draw a generalizable new knowledge for the potential treatment scenario which helps in prevention and cure of diabetic renal complications.

\section{REFERENCES}

1. Kiconco R, Rugera SP, Kiwanuka GN. Microalbuminuria and Traditional Serum Biomarkers of Nephropathy among Diabetic Patients at Mbarara Regional Referral Hospital in South Western Uganda. Journal of Diabetes Research. 2019 Dec 16;2019.

2. Dhinakaran T. Clinical Approach to Renal Disease in Diabetes, 1st ed. New Delhi: Jaypee Brothers Medical Publishers (P) Ltd; 2015: p.14-15

3. Dhinakaran T. Clinical Approach to Renal Disease in Diabetes, 1st ed. New Delhi: Jaypee Brothers Medical Publishers (p) Ltd; 2015: p. 65

4. Cefalu WT, Berg EG, Saraco M, Petersen MP, Uelmen S, Robinson S. Microvascular Complications and Foot Care: Standards of Medical Care in Diabetes-2019. Diabetes Care. 2019 Jan 1;42:S124-38.

5. Susruta. Illustrated Susruta Samhita (Text, English translation, Notes, Appendices and Index), Reprint ed. Varanasi: Cahwkhambha Orientalia; 2010: p. 163

6. Gayadasa. Susruta Samhita of Susruta with the Nibandhasangraha Commentary of Sri Dalhanacharya and the Nyayacandrika Panjika of Sri Gayadasacharya, Reprint ed. Varanasi: Chaukhambha Sanskrit Sansthan; 2017: p. 292

7. MacIsaac RJ, Ekinci EI, Jerums G. Markers of and risk factors for the development and progression of diabetic kidney disease. American journal of kidney diseases. 2014 Feb 1;63(2):S39-62.
8. Caraka. Caraka Samhita cikitsa sthana vatavyadhi cikitsa

http://niimh.nic.in/ebooks/ecaraka/?mod=home\&con= pro (accessed 24 october 2020).

9. Vagbhata. Principles of Ayurveda Explained in dexterous verse Astanga Hrdaya Vaghbhata Sutrasthana, Improved 2nd ed. Thrissur: Harisree Hospital; 2008: p. 308-315

10. Sulaiman MK. Diabetic nephropathy: recent advances in pathophysiology and challenges in dietary management. Diabetology \& metabolic syndrome. 2019 Dec $1 ; 11(1): 7$.

11. Caraka. e Caraka Samhita nidana sthana prameha nidana

http://niimh.nic.in/ebooks/ecaraka/? mod=home\&con= pro (accessed 24 october 2020).

12. Susruta. Illustrated Susruta Samhita (Text, English translation, Notes, Appendices and Index), Reprint ed. Varanasi: Cahwkhambha Orientalia; 2010: p. 505

13. Muskiet MH, Wheeler DC, Heerspink HJ. New pharmacological strategies for protecting kidney function in type 2 diabetes. The Lancet Diabetes \& Endocrinology. 2019 May 1;7(5):397-412.

\section{Source of Support: Nil Conflict of Interest: None Declared}

How to cite this URL: Binsha Salim et al: Diabetes Induced Microalbuminuria - A Critical Review. International Ayurvedic Medical Journal \{online\} 2020 \{cited November, 2020\} Available from: http://www.iamj.in/posts/images/upload/5137 5140.pdf 